Gut, 1977, 18, 631-635

\title{
Cimetidine and the gastric mucosal barrier
}

\author{
G. S. KENYON, I. F. ANSELL, AND D. C. CARTER \\ From the Department of Clinical Surgery, Edinburgh University Medical School, Edinburgh
}

SUMMARY The histamine $\mathrm{H}_{2}$-receptor antagonist, cimetidine, when given topically or parenterally, did not affect net luminal $\mathrm{Na}^{+}$gain or net luminal $\mathrm{H}^{+}$loss in vagally-denervated pouches of antrectomised dogs. Cimetidine did not affect disruption of the mucosal barrier by $5 \mathrm{mmol} / \mathrm{l}$ or $20 \mathrm{mmol} / \mathrm{l}$ sodium taurocholate.

The histamine $\mathrm{H}_{2}$-receptor antagonists are potent inhibitors of gastric secretion and are likely to prove useful in the treatment of peptic ulcer (Black et al., 1972; Milton-Thompson et al., 1974; Blackwood et al., 1976). Previous studies in our laboratory have shown that, while the $\mathrm{H}_{2}$-receptor antagonist metiamide does not protect the canine gastric mucosal barrier against permeability changes induced by sodium taurocholate solution, the compound does not in itself increase mucosal permeability to hydrogen or sodium ion (O'Brien and Carter, 1975). Metiamide has now been superseded by the apparently non-toxic compound cimetidine (Brimblecombe et al., 1975; Burland et al., 1975), and it is important to define the effect of this new compound on the mucosal barrier before its widespread clinical use. The present studies were therefore undertaken to define the effect of cimetidine on hydrogen and sodium movement across the gastric mucosa in an experimental model, and to determine the effect of cimetidine on permeability changes induced by the barrier breaker, sodium taurocholate.

\section{Methods}

Three male mongrel dogs weighing 12,15 , and $17 \mathrm{~kg}$ were prepared by antrectomy and construction of a vagally denervated (Heidenhain) pouch drained to the exterior by a vitallium cannula. No experiments were performed in the month after surgery, during which the animals were trained to the stand.

The animals were deprived of food, but not water, for 18 hours before the start of each experiment. All experiments consisted of six 30-minute periods. Twenty millilitres of solution containing a known

Received for publication 20 December 1976 amount of $\mathrm{Na}^{+}$and $\mathrm{H}^{+}$ion were instilled into the gastric pouch at the beginning of each period, mixed thoroughly by repeated withdrawal and instillation using a $20 \mathrm{ml}$ syringe attached to the cannula, and a 5 ml sample (initial sample) removed to measure $\mathrm{Na}^{+}$ and $\mathrm{H}^{+}$ion concentration. The remaining $15 \mathrm{ml}$ were retained in the pouch for 30 minutes, and after further thorough mixing a further $5 \mathrm{ml}$ aliquot (final sample) was removed to determine $\mathrm{Na}^{+}$and $\mathrm{H}^{+}$ concentration. The remaining fluid was discarded and the next period commenced.

A standard basal solution was instilled during periods $1,2,4,5$, and 6 during all tests, while period 3 was used to instil solutions containing test substances. Control tests were performed by instilling basal solution in all six periods. Basal solution consisted of $80 \mathrm{mmol} / 1 \mathrm{HCl}$ made isotonic with $\mathrm{NaCl}$.

The test solutions instilled during period 3 were (1) taurocholate solution, (2) cimetidine solution, or (3) a combined solution of cimetidine in taurocholate solution. The taurocholate solution consisted of basal solution in which either $5 \mathrm{mmol} / 1$ or $20 \mathrm{mmol} / \mathrm{l}$ sodium taurocholate (Koch Light) replaced equivalent amounts of $\mathrm{NaCl}$.

The cimetidine solution consisted of $200 \mathrm{mg}$ cimetidine ( $\mathrm{N}^{\prime}$ '-cyano-N-methyl-N'-\{2-[(5-methylimidazol-4-yl)methylthio] ethyl $\}$ guanidine) dissolved in $20 \mathrm{ml}$ basal solution. The combined solution consisted of $200 \mathrm{mg}$ cimetidine dissolved in either 5 $\mathrm{mmol} / 1$ or $20 \mathrm{mmol} / \mathrm{l}$ taurocholate solution.

In a further series of experiments, the effect of parenteral cimetidine on mucosal permeability was assessed by giving a bolus intravenous injection of $200 \mathrm{mg}$ of the compound at the beginning of period 2 , and instilling basal solution in all six periods. The effect of parenteral cimetidine on permeability changes induced by $5 \mathrm{mmol} / \mathrm{l}$ taurocholate solution was assessed by injecting $200 \mathrm{mg}$ of the compound 
before period 2, and instilling $5 \mathrm{mmol} / \mathrm{l}$ taurocholate solution during period 3 .

To minimise error caused by incomplete recovery of fluid from the pouch, polyethylene glycol labelled with $\mathrm{C}^{\mathbf{1 4}}$ (New England Nuclear) was added to all solutions as a volume marker, and unlabelled polyethylene glycol (1 $\mathrm{g}$ per litre) was also added to prevent loss of the labelled material by surface adherence.

The initial and final samples from each period were assayed for $\mathrm{Na}^{+}$ion concentration by flame photometry (IL 343, Digital Flame Photometer, Instrumentation Lab. Inc.), and for $\mathrm{H}^{+}$ion concentration using an automatic titrator (Radiometer, Copenhagen) and glass electrode. The amount of $100 \mathrm{mmol} /$ $1 \mathrm{NaOH}$ solution required to bring the sample to $\mathrm{pH}$ 7.0 was determined and an aliquot of the derived neutral solution was then added to liquid scintillant (NE 260, Nuclear Chicago) and $\mathrm{C}^{14}$ activity determined by scintillation counting. Knowing the initial volume instilled at the start of each period, the amount of $100 \mathrm{mmol} / \mathrm{l} \mathrm{NaOH}$ solution needed to neutralise the initial and final sample from each period, and the change in $\mathrm{C}^{14}$ activity over each period, the difference between the initial and final mass of $\mathrm{Na}^{+}$and $\mathrm{H}^{+}$could be calculated as: difference in mass $=$

(final concentration $\times$ final volume)

- (initial concentration $\times$ initial volume).

Two tests were carried out in each of the three dogs at each stage of the experiments, and the mean \pm SEM $(\mu \mathrm{mol} / 30 \mathrm{~min})$ for the change in mass of each ion calculated from the six results available for each 30 minute period.

The statistical significance of the difference between changes in ion mass has been assessed by comparing periods 2 and 3 within each set of experiments, and by comparing period 3 after exposure to test solutions with period 3 in control tests using basal solution. The analysis of the six pairs of results available was performed using a $t$ test for paired data.

\section{Results}

\section{CONTROL TESTS}

Instillation of basal solution during all six 30-minute periods produced a small but constant gain in $\mathrm{Na}^{+}$by the pouch fluid, and a comparable small but constant loss of $\mathrm{H}^{+}$, once the initial period was completed (Fig. 1). There was no statistically significant difference between periods 2 and 3 when gain of $\mathrm{Na}^{+}$ or loss of $\mathrm{H}^{+}$ion was assessed (Table 1).

CIMETIDINE SOLUTION

Instillation of cimetidine solution during period 3 did not produce any statistically significant alteration when the pattern of ion mass changes was compared with that observed in control tests (Fig. 1; Table 1).

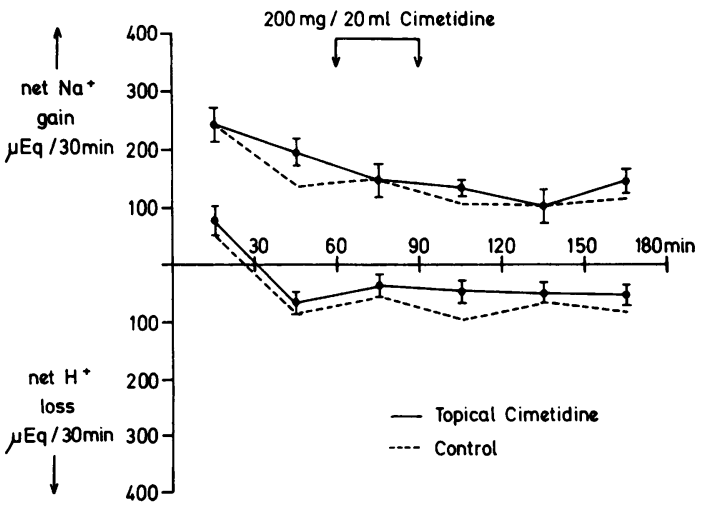

Fig. 1 Effect of basal solution and cimetidine solution on net $\mathrm{Na}^{+}$gain and net $\mathrm{H}^{+}$loss. Each point represents the mean $\pm S E M$ from six experiments.

Table $1 \mathrm{Net} \mathrm{Na}^{+}$gain and $\mathrm{H}^{+}$loss under basal conditions and after administration of topical or parenteral cimetidine

\begin{tabular}{|c|c|c|c|c|c|}
\hline & $\begin{array}{l}\text { Basal } \\
\text { solution } \\
\text { alone }\end{array}$ & $\begin{array}{l}\text { Topical } \\
\text { cimetidine }\end{array}$ & $\mathbf{P}$ & $\begin{array}{l}\text { Parenteral } \\
\text { cimetidine }\end{array}$ & $\mathbf{P}$ \\
\hline \multicolumn{6}{|c|}{$\mathrm{Net} \mathrm{Na}^{+}$gain } \\
\hline Period 2 & $\begin{array}{l}+140 \\
\pm \quad 26\end{array}$ & $\begin{array}{l}+183 \\
\pm \quad 19\end{array}$ & NS & $\begin{array}{r}+175 \\
\pm \quad 37\end{array}$ & NS \\
\hline Period 3 & $\begin{array}{r}+146 \\
\pm \quad 14\end{array}$ & $\begin{array}{l}+148 \\
\pm \quad 26\end{array}$ & NS & $\begin{array}{l}+171 \\
\pm \quad 61\end{array}$ & NS \\
\hline $\mathbf{P}$ & NS & $<0.05$ & & NS & \\
\hline \multicolumn{6}{|l|}{ Net $\mathbf{H}^{+}$loss } \\
\hline Period 2 & $\begin{array}{l}-83 \\
\pm 28\end{array}$ & $\begin{array}{l}-65 \\
\pm 14\end{array}$ & NS & $\begin{array}{l}-94 \\
\pm 37\end{array}$ & NS \\
\hline Period 3 & $\begin{array}{l}=57 \\
\pm 20\end{array}$ & $\begin{array}{l}=37 \\
\pm 19\end{array}$ & NS & $\begin{array}{l}-73 \\
\pm 17\end{array}$ & NS \\
\hline $\mathbf{P}$ & NS & NS & & NS & \\
\hline
\end{tabular}

Net ion gain or loss expressed in $\mu \mathrm{mol} / 30 \mathrm{~min}$; each figure is the mean \pm SEM of six values.

TAUROCHOLATE SOLUTION

Instillation of either $5 \mathrm{mmol} / 1$ or $20 \mathrm{mmol} / 1$ sodium taurocholate solution during period 3 caused a statistically significant increase in $\mathrm{Na}^{+}$net gain and $\mathrm{H}^{+}$net loss when compared with the preceding period 2 (Figs. 2 and 3; Table 2). These changes were greater after exposure to the higher concentration of taurocholate.

\section{COMBINED SOLUTION}

The addition of $200 \mathrm{mg}$ cimetidine to either concentration of taurocholate solution did not reduce 


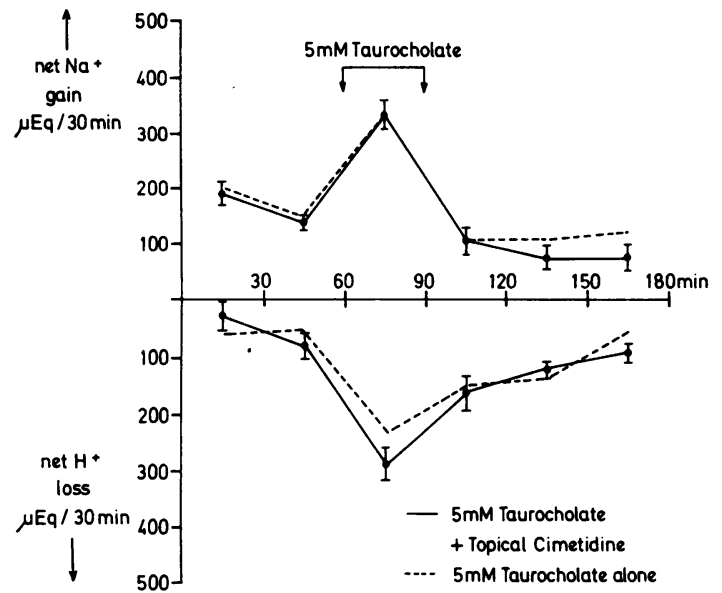

Fig. 2 Effect of topical cimetidine on net $\mathrm{Na}^{+}$gain and net $\mathrm{H}^{+}$loss induced by $5 \mathrm{mmol} / \mathrm{l}$ taurocholate solution. Each point represents the mean $\pm S E M$ from six experiments.

the net $\mathrm{Na}^{+}$gain or net $\mathrm{H}^{+}$loss induced by taurocholate alone (Figs 2 and 3). In the case of $5 \mathrm{mmol} / 1$ taurocholate solution, the addition of cimetidine actually increased net $\mathrm{H}^{+}$loss to a statistically significant extent. The mean net loss of $\mathrm{H}^{+}$ion during period 3 was $-289 \mu \mathrm{mol} / 30 \mathrm{~min}$ after exposure to the combined solution, as opposed to $-235 \mu \mathrm{mol} / 30 \mathrm{~min}$ after exposure to taurocholate alone (Table 2).

\section{PARENTERAL CIMETIDINE}

Injection of $200 \mathrm{mg}$ cimetidine before period $2 \mathrm{did}$ not produce any statistically significant alteration in the pattern of ion movement when compared with control tests (Fig. 4; Table 1).

Injection of cimetidine did not prevent the changes

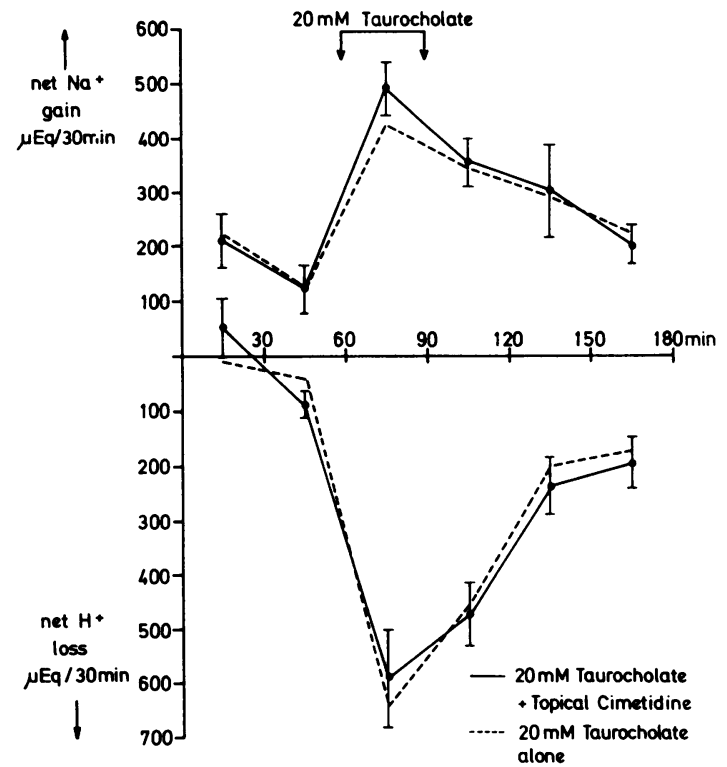

Fig. 3 Effect of cimetidine on net $\mathrm{Na}^{+}$gain and net $\mathrm{H}^{+}$loss induced by $20 \mathrm{mmol} / \mathrm{l}$ taurocholate solution. Each point represents the mean $\pm S E M$ from six experiments.

in permeability induced by instillation of $5 \mathrm{mmol} / \mathrm{l}$ taurocholate during period 3 (Fig. 5); indeed, net $\mathrm{H}^{+}$loss was significantly increased when compared with period 3 in tests where $5 \mathrm{mmol} / 1$ taurocholate was instilled without previous injection of cimetidine.

\section{Discussion}

Damage to the gastric mucosal barrier resulting in increased permeability to $\mathrm{H}^{+}$ion may be important in the aetiology of gastritis and gastric ulcer.(Rhodes,

Table $2 \mathrm{Net} \mathrm{Na}^{+}$gain and $\mathrm{H}^{+}$loss after exposure to taurocholate solutions with and without administration of cimetidine ( $\mu$ mol/30 min; mean $\pm S E M$ of six values)

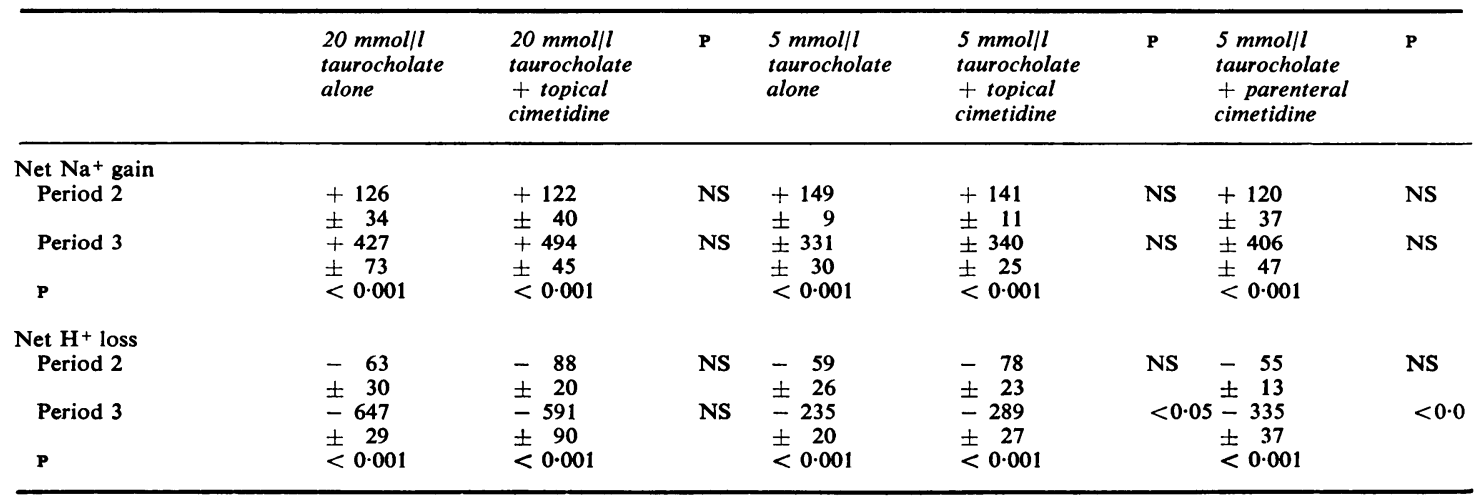




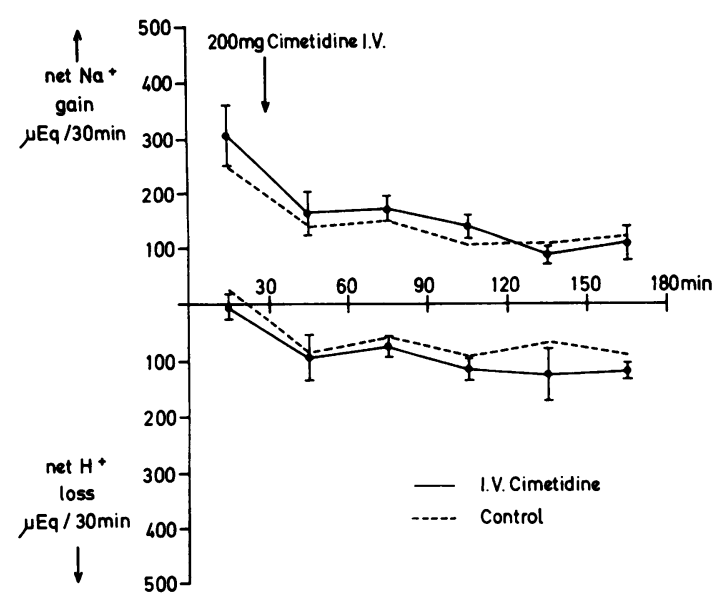

Fig. 4 Effect of parenteral cimetidine on net $\mathrm{Na}^{+}$ gain and net $\mathrm{H}^{+}$loss. Each point represents the mean $\pm S E M$ from six experiments.

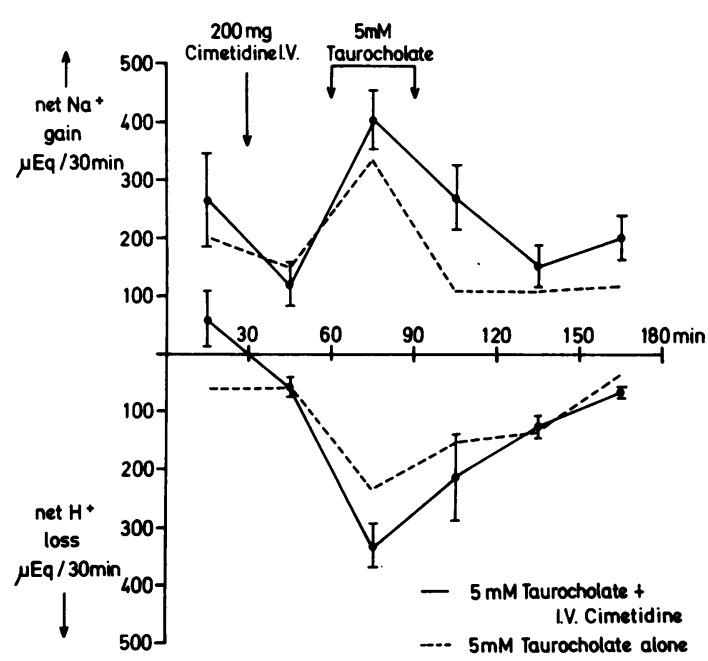

Fig. 5 Effect of parenteral cimetidine on net $\mathrm{Na}^{+}$ gain and net $\mathrm{H}^{+}$loss induced by $5 \mathrm{mmol} / \mathrm{l}$ taurocholate solution. Each point represents the mean $\pm S E M$ from six experiments.

1972). The barrier can be damaged by a number of agents (Davenport, 1964, 1966, 1967; Ivey et al., 1970) and release of mucosal histamine is considered to be of central importance in the pathophysiology of barrier disruption (Johnson, 1966, 1968).

Output of $\mathrm{Na}^{+}$across an intact mucosa is usually less than $300 \mu \mathrm{mol} / 30 \mathrm{~min}$ in gastric pouches of the type used in the present study (Davenport and Barr, 1973). After exposure to $20 \mathrm{mmol} / 1$ taurocholate we have observed net $\mathrm{Na}^{+}$gains in excess of $400 \mu \mathrm{mol} /$
$30 \mathrm{~min}$, but this increase in mucosal permeability was not reduced by concurrent cimetidine instillation (Table 2). Exposure to $5 \mathrm{mmol} / 1$ taurocholate produced net $\mathrm{Na}^{+}$gains just exceeding $300 \mu \mathrm{mol} / 30 \mathrm{~min}$, suggesting that this was a threshold concentration of taurocholate for barrier disruption in the animals used. However, even when given in conjunction with this lower concentration of taurocholate, cimetidine failed to prevent increases in net $\mathrm{Na}^{+}$gain. Previous intravenous injection of cimetidine also failed to prevent increases in net $\mathrm{Na}^{+}$flux induced by $5 \mathrm{mmol} / \mathrm{l}$ taurocholate (Table 2).

Changes in mass of $\mathrm{H}^{+}$ion are generally accepted as less reliable indices of barrier disruption. After severe mucosal damage, histamine release may stimulate $\mathrm{H}^{+}$secretion by the pouch mucosa, thus masking increased $\mathrm{H}^{+}$back-diffusion from the pouch lumen (Davenport, 1970). There is no evidence from the present study that cimetidine prevented the increased net loss of $\mathrm{H}^{+}$induced by taurocholate instillation. At first sight, the small but statistically significant increase in net $\mathrm{H}^{+}$loss, noted when cimetidine was given in association with 5 $\mathrm{mmol} / \mathrm{l}$ taurocholate (Table 2), could reflect inhibition of pouch acid secretion by cimetidine. However, the absence of a similar pattern after exposure to a higher concentration of taurocholate suggests that these differences are caused by experimental variation rather than by a biologically significant mechanism involving histamine $\mathrm{H}_{2}$-receptor blockade.

The failure of $\mathrm{H}_{2}$-receptor antagonists to protect against barrier disruption by taurocholate is not unexpected. If histamine has central importance in the pathophysiology of disruption, it seems probable that its deleterious effects will be mediated by $\mathrm{H}_{1}$ as well as $\mathrm{H}_{2}$ receptors in the underlying tissues. Rees and his associates (1976) have recently produced support for this thesis by demonstrating that, in an animal model similar to that used in the present study, barrier disruption by taurocholate can be prevented by a combination of mepyramine $\left(\mathrm{H}_{1}\right.$ receptor antagonist) and metiamide $\left(\mathrm{H}_{2}\right.$-receptor antagonist), whereas administration of either agent alone did not prevent taurocholate-indiced increases in ion flux.

Although we have been unable to detect any protective action of cimetidine on the mucosal barrier challenged by taurocholate, our results in no way detract from the potential value of this compound in the treatment of conditions such as gastritis and gastric ulceration. Cimetidine showed no signs of increasing mucosal permeability when given in the absence of taurocholate (Table 1), and, as a potent inhibitor of gastric secretion, the compound could prove valuable by reducing the amount of secreted $\mathrm{H}^{+}$ ion available to exploit a mucosal barrier damaged by 
agents such as bile salts. The encouraging preliminary results reported from $\mathrm{H}_{2}$-receptor antagonist therapy in patients with stress-induced upper gastrointestinal haemorrhage (MacDonald et al., 1976) and in prevention of haemorrhagic gastritis in patients with liver disease (Bailey et al., 1976), lend support to this suggestion.

The authors gratefully acknowledge the continued support of Professor A. P. M. Forrest, and Miss P. Muir for her typing assistance. The cimetidine was provided by Dr R. Brimblecombe of Smith, Kline, and French, Ltd. During these studies $\mathrm{Mr}$ D. C. Carter was supported by the Wellcome Trust and Dr G. S. Kenyon was in receipt of an Edinburgh University Faculty of Medicine Scholarship.

\section{References}

Bailey, R. J., MacDougall, B. R. D., and Williams, R. (1976). A controlled trial of $\mathbf{H}_{2}$-receptor antagonists in prophylaxis of bleeding from gastrointestinal erosions in fulminant hepatic failure. Gut, 17, 389 (Abstract).

Black, J. W., Duncan, W. A. M., Durant, C. J., Ganellin, C. R., and Parsons, E. M. (1972). Definition and antagonism of histamine $\mathrm{H}_{2}$ receptors. Nature, 236, 385-390.

Blackwood, W. S., Pickard, R. G., Maudgal, D. P., Lawrence, D., and Northfield, T. C. (1976). Cimetidine in duodenal ulcer. Lancet, 2, 174-176.

Brimblecombe, R. W., Duncan, W. A. M., Durant, G. J., Emmett, J. C., Ganellin, C. R., and Parsons, M. E. (1975). Cimetidine-a non-thiourea $\mathrm{H}_{2}$-receptor antagonist. Journal of Internal Medical Research, 3, 86-92.

Burland, W. L., Duncan, W. A. M., Hesselbo, T., Mills, J. G., Sharpe, P. C., Haggie, S. J., and Wvllie, J. H. (1975). Pharmacological evaluation of cimetidine, a new histamine $\mathrm{H}_{2}$-receptor antagonist, in healthy man. British Journal of Clinical Pharmacology, 2, 481-486.
Davenport, H. W. (1964). Gastric mucosal injury by fatty and acetylsalicylic acids. Gastroenterology, 46, 245-253.

Davenport, H. W. (1966). Fluid produced by the gastric mucosa during damage by acetic and salicylic acids. Gastroenterology, 50, 487-499.

Davenport, H. W. (1967). Ethanol damage to canine oxyntic glandular mucosa. Proceedings of the Society for Experimental Biology and Medicine, 126, 657-662.

Davenport, H. W. (1970). Back diffusion of acid through the gastric mucosa and its physiological consequences. In Progress in Gastroenterology, pp. 42-56. Edited by G. B. J. Glass. Grune and Stratton: New York.

Davenport, H. W., and Barr, L. L. (1973). Failure of ischemia to break the dog's gastric mucosal barrier. Gastroenterology, 65, 619-624.

Ivey, K. J., DenBesten, L., and Clifton, J. A. (1970). Effect of bile salts on ionic movement across the human gastric mucosa. Gastroenterology, 59, 683-690.

Johnson, L. R. (1966). Histamine liberation by gastric mucosa of pylorus-ligated rats damaged by acetic or salicylic acids. Proceedings of the Society for Experimental Biology and Medicine, 121, 384-386.

Johnson, L. R. (1968). Source of the histamine released during damage to the gastric mucosa by acetic acid. Gastroenterology, 54, 8-15.

MacDonald, A. S., Steele, B. J., and Bottomley, M. G. (1976). Treatment of stress-induced upper gastrointestinal haemorrhage with metiamide. Lancet, 1, 68-70.

Milton-Thompson, G. J., Williams, J. G., Jenkins, D. J. A., and Misiewicz, J. J. (1974). Inhibition of nocturnal acid secretion in duodenal ulcer by one oral dose of metiamide. Lancet, 1, 693-694.

O'Brien, P. E., and Carter, D. C. (1975). Effect of gastric secretory inhibitors on the gastric mucosal barrier. Gut, 16, 437-442.

Rees. W. D. W., Rhodes, J., Wheeler, M. H., Meek, M. E., and Newcombe, R. G. (1976). Role of histamine receptors in the patho-physiology of gastric mucosal damage. Gut, 17, 388 (Abstract).

Rhodes, J. (1972). Etiology of gastric ulcer. Gastroenterology, $63,171-182$ 